\title{
Leadership Learning through Student-Centered and Inquiry-Focused Approaches to Teaching Adaptive Leadership
}

\author{
Paige Haber-Curran, Ph.D. \\ Assistant Professor \\ Department of Counseling, Leadership, Adult Education, and School Psychology \\ Texas State University-San Marcos \\ San Marcos, TX \\ ph31@txstate.edu
}

Daniel Tillapaugh, Ph.D.

Postdoctoral Fellow in Higher Education

College of Education and Human Development

University of Maine

Orono, ME

daniel.tillapaugh@maine.edu

\begin{abstract}
This qualitative study examines student learning about leadership across three sections of a capstone course in an undergraduate leadership minor. Qualitative methods were informed by exploratory case study analysis and phenomenology. Student-centered and inquiry-focused pedagogical approaches, including case-inpoint, action inquiry, and problem-based learning, informed classroom teaching and the classroom environment. Engaged in pedagogy steeped in a balance of challenge and support, students gained an increased sense of self, clarity of purpose and vocation, and integration of their leadership practices in and out of the classroom. Students' understandings of the concept of leadership were also broadened; they recognized the importance of diverse perspectives and roles, began to understand leadership as systemic and interdependent, and emphasized relationship building. Findings suggest three prominent experiences as contributing to students' learning - reflection, feedback, and engaging in the group process. Implications for leadership education are discussed and areas for future research are identified.
\end{abstract}

\section{Introduction}

Leadership development is a prominent outcome of higher education, evidenced by the emphasis on leadership in many institutional mission statements and the inclusion of leadership in student learning outcomes (Council for the Advancement of Standards in Higher Education, 2009; Keeling, 2004). Over the past 30 years the number and types of programs existing to develop the leadership 
capacity of students have increased, reflecting a variety of approaches to program delivery and curriculum emphases within the classroom and outside of the classroom through co-curricular initiatives (Komives, 2011). This growing emphasis on leadership development in higher education begs the questions of the best practices in teaching leadership and what students learn about leadership through different leadership courses and programs. The current study examines student leadership development and learning in an undergraduate capstone leadership course.

\section{Leadership Teaching and Learning}

Leadership is embraced by many as a capacity, process, or ability that can be learned and developed, and thus as something that can be taught (Daloz Parks, 2005; Northouse, 2007). As such, multiple teaching and facilitation strategies are employed to address college student leadership outcomes (Haber, 2011; Roberts \& Ullom, 1989). As is demonstrated within the descriptive and conceptual literature on leadership programs, leadership educators design and implement a diverse array of leadership programs to address a variety of educational outcomes (Brungardt, Greenleaf, Brungardt, \& Arensdorf, 2006; Scroggs, Sattler, \& McMillan, 2009; Seemiller, 2006; Zimmerman-Oster \& Burkhardt, 1999). Leadership education initiatives exist in the forms of leadership courses, minors, majors, workshop series, retreats, certificate programs, peer leadership teams, multicultural and women's leadership programs, outdoor leadership programs, service learning programs, and living-learning programs (Dugan et al., 2011; Smist, 2011).

Research on leadership programs is also diverse, spanning an array of program types and focusing on a variety of outcomes (Binard \& Brungardt, 1997; Cress, Astin, Zimmerman-Oster, \& Burkhardt, 2001; DiPaolo, 2002; Dugan, 2011; Eich, 2008; Posner, 2009; Williams \& Townsend, 2003). The two most comprehensive examinations of collegiate leadership programs are the Kellogg Foundation's Leadership in the Making project from the 1990s and the more recent MultiInstitutional Study of Leadership (MSL) (Dugan et al., 2011; Zimmerman-Oster $\&$ Burkhardt, 1999). The Kellogg Foundation assisted with the surge of the development of leadership programs in the past 30 years in helping fund 31 leadership programs, most of which existed on college campuses (ZimmermanOster \& Burkhardt, 1999). Ten of the programs were examined in further depth to identify the effectiveness of the leadership programs in enhancing participants' leadership skills and knowledge. The findings suggested a number of significant positive leadership outcomes (Cress et al., 2001).

The MSL is a national leadership study focusing on college student leadership development and the impact of the collegiate experience on a variety of outcomes including the eight values of socially responsible leadership (Komives \& Wagner, 2009). Findings from the MSL suggested that shorter-term leadership experiences (such as one-time workshops or retreats) had a more significant impact on 
measures of socially responsible leadership than programs that were moderateterm or long-term in nature and that long-term leadership programs had a negative influence on these outcomes (Dugan \& Komives, 2007). The researchers identified challenges in assessing the impact of such programs due to the vast diversity of leadership programs within the three categories of short, moderate, and long-term in addition to the varied leadership frameworks and assumptions about leadership guiding the programs.

Responding to this challenge, Dugan and colleagues (2011) conducted a subsequent study to further examine the influence of leadership programs by focusing more specifically on 16 different types of leadership experiences on the eight outcomes of socially responsible leadership. A number of the experiences such as leadership conferences, peer leadership teams, and multicultural leadership programs emerged as positive predictors for the leadership outcomes; some programs, including women's leadership programs, living-learning programs, and outdoor leadership programs were identified as negative predictors for certain outcomes (Dugan et al., 2011). In their discussion of implications, the researchers suggest further investigation on "how leadership interventions are designed and delivered" (Dugan et al., 2011, p. 77). Specifically, they identify the need for additional qualitative inquiry on individual leadership programs and the nature of these experiences in order to "significantly enhance the quality of programs" (p. 78). The current study responds to this need, providing qualitative inquiry into key components of a capstone leadership course and the resulting student learning in the course.

\section{Theoretical and Pedagogical Frameworks}

There is a need for additional focus on pedagogical approaches to teaching leadership and the outcomes of these efforts. This study addresses this need, focusing on the pedagogical approaches used in a capstone undergraduate leadership course and examining students' learning from the experience. While many theoretical underpinnings informed the course, the primary theoretical framework for the course was adaptive leadership (Heifetz \& Linsky, 2002). The pedagogical approach used to address the adaptive leadership framework pulled from multiple influences.

\section{Adaptive Leadership}

Adaptive leadership involves mobilizing people to address the ambiguous, significant challenges to which there are not readily available solutions (Heifetz \& Linsky, 2002). To do so, people must challenge their existing belief systems and behaviors as well as recognize the greater system and its dynamics that affect the leadership process. Using the metaphor of the dance floor and the balcony, Heifetz and Linsky (2002) contend that effective leadership involves the ability to understand a situation and its complexity with a balcony perspective while still being able to interact within the system and influence it by acting on the dance 
floor. With a myriad of increasingly complex and daunting challenges facing society today, leadership must encompass the recognition of multiple perspectives in understanding the world and various approaches to tackling these challenges. The traditional focus on leadership as a skill set or trait possessed by an extraordinary person is no longer appropriate and fails to address the leadership needs of today.

\section{Pedagogical Approach}

Teaching a curriculum that challenges traditional conceptions of leadership and promotes more contemporary and adaptive understandings of leadership calls for innovative pedagogical approaches. Higher education relies heavily on traditional pedagogical models that emphasize the memorization and recollection of information with minimal focus on critical examination, context, and application (Duch, Groh, \& Allen, 2001a). Accordingly, students do not fully engage with the content and often "fail to develop the full battery of skills and abilities desired in a contemporary college graduate" (p. 4).

Thus, pedagogical approaches are needed that challenge traditional notions of teaching and learning, inviting students to help construct their learning and engaging students in the learning process. Such pedagogical approaches help empower students, encourage them to become invested in their learning, and facilitate the development of interdependent relationships with peers and instructors (Baxter Magolda \& King, 2004; Duch, Groh, \& Allen, 2001b; Millis, 2010). This reframing of teaching and learning is particularly relevant for the field of leadership education, characterized by holistic development concerned with preparing people to "be responsible, together, in an increasingly interdependent world" (Huber, 2002, p. 27).

Notable pedagogies used within leadership education that facilitate student engagement and empowerment in the classroom are action inquiry (Torbert, 2004), case-in-point teaching (Daloz Parks, 2005), and problem-based learning (Barbour, 2006; Cunningham \& Cordeiro, 2006). Action inquiry engages students in reciprocal and mutual inquiry through reflecting in action on oneself, the situation, one's relationships, and the system as a whole (Torbert, 2004). By simultaneously engaging in action and reflection, the instructor and students gain increased awareness which can lead to greater leadership capacity and organizational effectiveness. As a pedagogical approach, action inquiry invites students to make meaning of their experiences and shape their own learning and the learning of their classmates. Exposure to this type of learning equips students with valuable skills of inquiry and reflection while actively engaging in leadership.

Case-in-point pedagogy is similar to action inquiry, as it involves examining oneself, others, and the larger system while it is unfolding in action. Framed as a pedagogical tool to teach adaptive leadership, case-in-point pedagogy involves 
focusing on the here and now by using the dynamics presently occurring with the group to examine and practice leadership (Daloz Parks, 2005). Through this students' attention is drawn to the complex nature of systems in which leadership takes place - "made up of a number of different factions and acted on by multiple forces" (Daloz Parks, 2005, p. 7) and thereby, students examine their role within the system. This highlights for students the importance of examining one's own perceptions, beliefs, and behaviors as well as collaborating with others to mobilize change.

The final pedagogical framework that creates an environment that empowers and engages students to learn is problem-based learning. In problem-based learning, students learn through engaging with complex and real-world problems. The problems require "collective skill at acquiring, communicating, and integrating information" (Duch et al., 2001a, p. 6) with an emphasis on critical thinking. This pedagogical approach allows students to bridge theory to practice through engaging with others and through gaining exposure to the complexity of adaptive leadership challenges.

\section{Methods}

In this study we sought to identify students' learning about themselves, others, and leadership through their experiences in a capstone leadership course that focused on adaptive leadership and that involved innovative pedagogical approaches. To address this purpose, we employed two qualitative research methods that blended aspects of qualitative methodologies. The study reflected components of (a) exploratory case study analysis and (b) phenomenology. Integrating and blending aspects of methodological approaches is common within qualitative research (Creswell, 2007).

The use of qualitative case study was chosen due to fact that we, as researchers, were "interested in insight, discovery, and interpretation rather than hypothesis testing" (Merriam, 2009, p. 42). Merriam discusses the importance of a bounded system when using a case study approach, which for the purpose of this research was the students participating in the capstone course. One of the characteristics of qualitative case study analysis is that it is heuristic and "illuminate[s] the reader's understanding of the phenomenon under study" (p. 44).

Phenomenology, which examines a phenomenon through a group of individuals' lives experiences, also informed the study's methodology (Creswell, 2007). The phenomenon in the case this study was the common experience of being in this student-centered and inquiry-focused leadership course; understanding common experiences, such as this specific course, is helpful in developing a "deeper understanding about the features of the phenomenon" (Creswell, 2007, p. 60). Together, phenomenology and case study methodology enabled us to explore multiple dimensions of our students' learning and create a rich, deep description of the phenomenon (Creswell, 2007; Guba \& Lincoln, 1985). 


\section{Context and Participants}

The capstone leadership course is the final core course in the Leadership Studies Minor at The University of San Diego. With a focus on adaptive leadership, the course is designed to provide an integrative and hands-on experience for students to apply their leadership learning to practice. Through the use of the case-in-point, action-inquiry, and problem-based learning the students are tasked with collaboratively taking responsibility for their learning. In other words, their leadership "problem" is to work together to create the course. The course description, outcomes, and some assignments are provided. The class determines the other aspects of the course including expectations, assessments, activities, and assignments. The instructor serves in a facilitator and consultant role, supporting and challenging the students in the process.

Participants in this study were students enrolled in the capstone course. A total of 28 students participated in the study, spanning three sections of the course taught from 2008 to 2010 . The students were traditional-aged undergraduate students, and all but two of the students were juniors or seniors. Reflecting the demographic profile of the Leadership Studies minor, the participants were approximately $80 \%$ White and $70 \%$ Female. Many of the students were active student leaders on campus, serving as positional leaders within student government, fraternities and sororities, and other student organizations such as resident assistants and student employee positions. Students' majors were varied, with the most common majors being Communication Studies, Business, and Psychology. There was a wide range of geographical diversity among the students; however, the majority was originally from the Southwest region of the United States.

\section{Data Collection and Analysis}

Participants' final reflection papers in the course were the source of data for the study. The length of the papers ranged from four pages to approximately 15 pages, and the prompts of the papers focused on students' learning through the course with a focus on their understanding of themselves, of the group process, and of leadership. Students were invited to participate in the study after the end of each course in order to capture the naturalistic intention of the study (Klenke, 2008); thus, the papers were written for the natural setting of the course rather than for the research study. This approach was used due to the fact that the researchers recognized that students were submitting these papers as a course assignment, and the papers would be reviewed by their respective instructors. By asking for permission to analyze the content of their papers after the completion of the course, the researchers who originally read and graded these papers as instructors were reviewing the content with a specifically different lens. 
The papers were analyzed using content analysis, whereby researchers review and analyze documents to unveil their contents for discovery (Merriam, 2009). Specifically, thematic content analysis allowed for the identification of themes and patterns within the reflection papers. Both researchers reviewed all papers and used coding schemas to organize individual thoughts and ideas into collective themes (Boyatzis, 1998; Klenke, 2008). Data were organized and analyzed using the NVivo software package. To address issues of validity and reliability, identified themes were continuously compared back to the data sources. Additionally, in addressing intercoder agreement, the two researchers, examined the data first independently and then collectively during the various stages of the data analysis process to compare and finalize themes as well as to confirm the assignment of themes of the data (Klenke, 2008).

\section{Results}

Content analysis of participants' reflection papers revealed a number of findings of what students learned about themselves, others, and leadership as a result of the capstone leadership course. The student-centered and inquiry-focused pedagogical design used in the course incorporated three key learning experiences identified in the research as pivotal in the learning process - reflection, group process, and feedback. Influenced by these experiences, the students' learning fell into two main categories: having an increased self-awareness and developing a broader understanding of leadership, each of which included three sub-themes. Increased self-awareness included the sub-themes of (a) challenge and affirmation of leadership styles and roles, (b) clarity of one's purpose and vocation, and (c) integration of learning and experiences. Broader understanding of leadership included the sub-themes of (a) openness to diverse perspectives and roles, (b) leadership as systemic and interdependent, and (c) emphasis on relationship building.

Figure 1 depicts the model of students' learning, identifying instrumental learning experiences within the capstone course and the resulting outcomes of learning related to their increased self-awareness and broader view of leadership.

In this next section, we provide an overview of the pedagogical approaches students experienced in this capstone course and further discuss how students demonstrated growth related to the two main themes of increased self-awareness and broader view of leadership.

\section{Learning Experiences}

Students emphasized three key experiences instrumental in their learning process - participating in reflection, engaging in the group process, and providing and receiving feedback. Each of these experiences encompassed intrapersonal and interpersonal aspects. For example, reflection happened both individually and collectively as a class, and engaging in the group process and in feedback 
involved an intrapersonal level of working with others and an intrapersonal level of making meaning of the experiences and examining oneself in the experience.

Reflection was a key activity that helped students internalize and make meaning of what they were learning and what they were experiencing in the course. While all of the students had been exposed to reflection in past courses, many noted that this was the course in which they felt that reflection was most instrumental in their learning.

Figure 1

Model of Students' Learning

Learning Experiences
$\begin{array}{r}\text { Reflection } \\ \text { Group Process } \\ \text { Feedback }\end{array}$

Students examined themselves and their group process in individual reflection papers. One student wrote:

- I have developed a newfound understanding for reflection. I believe that reflection is one of the most important parts of the learning process...Reflection can help formulate meanings that change, mold, or shift my behaviors.

Collective reflection was also incorporated through reflective group discussions in class and through online forums students were able to engage with each other in a reflective manner. In discussing the utility of reflection, one student recognized how reflection helped him be more aware in how he was engaging with the learning process:

- The reflections provided an outlet for me to vent, but they also served a better purpose in how I was going to learn. With the comments provided 
by the professor and [through reading my peers' reflections on the online forum], I began to see that I was not alone in my thinking, but also that my thought process may not have been the best one.

Coupled with reflection was the overall process in which the group engaged. Group dynamics was a key aspect of the group process and encompassed authority dynamics, leadership styles and roles, and conflict. The design of the course challenged traditional notions of classroom learning, and authority dynamics were significantly altered. One student wrote:

- $[\mathrm{N}]$ ever before this class have I engaged in a process of group leadership, in which everyone was just as much of a primary stakeholder in the decision-making and success of the group as everyone else."

Another student discussed that through the group process he was able to reexamine his role within the course:

- I took the opportunity during the conflict to remain quiet and listen. I wanted to hear what others had to say regarding their perspectives on the class, while in turn, hoping that I can learn from listening, not talking aimlessly.

The process caused some students frustration and anxiety, but those students were able to use the experience as an opportunity to learn. This is evident in a student's remarks:

- Even though I hated this class at many times, I am unable to deny the fact that I gained much insight about myself and about how I work on a team.

Another key aspect of the group process was the relationships formed among the class and how these relationships enabled the group to work together in an effective manner. In discussing the relationships built among the class, one student wrote:

- Our class developed a community of care. We were all eager to learn, and realized that we could learn so much from each other. This was aided by the trust we developed in the classroom.

Further, one student emphasized the progress that the group made:

- Not only did I see myself grow as an individual but also I saw our class grow as a group.

Class check-ins, which took many forms of allowing the individual group members to share how they were doing and what things were on their mind, were significant for building trust and connections within the group. One student wrote: 
- The check-ins broke down our walls towards other people and allowed all of us to grow together as a group with a new perspective of one another.

Feedback was another instrumental learning experience for students in the course. Many students expressed fear in giving and receiving feedback. For many, the feedback experiences were instrumental in students' development of selfawareness. In describing her process of reading through the feedback provided, one student wrote:

- Tears began to stream down my face... The feedback was a bit overwhelming in that it addressed many factors about myself and how others view me that were difficult to come to terms with. I did not only get emotional because of the negative, more disapproving feedback, but also because of the positive and inspiring things people had to say.

Along with being powerful experiences for students individually, the feedback exercises also served as beneficial for the group as a whole, as one student discussed:

- What I have learned through our feedback exercises that I was not conscious of before is how feedback can act as an instrument for relationship building.

\section{Increased Self-Awareness}

A significant area of learning identified by students in the study was an increased understanding of self. In discussing this learning, one student wrote:

- I do not believe it is selfish to say that what I learned most this semester was me. I learned who I am, the causes behind those effects, my greater goals, my dreams, my strengths, my weaknesses.

Another student, who was more skeptical of this outcome, also shared her transformation:

- At first, when I heard the desire of a couple [classmates] to take this class as an opportunity to learn about themselves, I balked at the idea. My first thought was, "That sounds so selfish!" Little did I know, however, that the self would be the most important theme stemming from the class and how effective it can be to take that time and understand one's self before trying to care for others.

The theme of increased self-awareness included the three prominent sub-themes of (a) challenge and affirmation of one's leadership styles and roles, (b) clarity of one's purpose and vocation, and (c) the integration one's learning and 
experiences. Each of these sub-themes contributed to an overall greater understanding of one's self, which students noted as being significant, and for some even transformational.

\section{Challenge and Affirmation of Leadership Styles and Roles}

Through the learning experiences of reflection, group process, and feedback describe above, students had ample opportunity to examine themselves with particular attention on their leadership styles and the roles in which they took on in the group. With a deeper understanding of self, students examined their personal leadership effectiveness. One student expressed that prior to the course she felt that she knew a lot about herself, but that she hadn't incorporated this awareness into her leadership style. She wrote:

- I know that I place the importance of others' emotions before mine. I did not realize that suppressing my emotions for the group made me come across as less passionate and unable to speak up for myself and my ideals.

Another student recognized that his tendencies of often speaking up and providing conflicting ideas had an effect on the group and his leadership effectiveness:

- I held the group back from progress and my comments needed reworking...I can understand how I would have been seen as annoying and holding the group back.

A few of the female students, after receiving feedback from peers, recognized their natural tendency to avoid confrontation, and therefore experimented with taking on different roles in the course, ultimately pushing themselves out of their comfort zones to take on a more assertive role. While nervous about their assertiveness, the reactions they received from the group were positive. One student wrote:

- I fully expected people to give me feedback that said I was overly confident, which would have reflected my own perceptions...It gave me great insight into my leadership style...I need to understand that it is perfectly fine to be more forceful when sharing my ideas- otherwise they will not get the respect that they deserve.

Similarly, a male student expressed affirmation in his relationship-focused style within the group, noting:

- The respect peers had for my strong relationship oriented style, from both women and men, was great...I want to be someone who is approachable and trustworthy, and someone that can bring a steady presence to a group. 
Some students expressed confusion and dissonance in their process of examining their behaviors and roles in a group. One student, who expressed an ongoing challenge with coming off as intimidating with peers wrote:

- It saddens me that I still come off in a [sic] intimidating way whether it is cold and uninterested or loud and opinionated...I have tried to be less intimidating and warmer but my efforts have not been responded to [sic].

A number of students translated their learning within the class to how they present themselves within groups outside of the class. In grappling with how to make meaning of his newfound understanding of self, one student began to challenge the masks and walls he had put up in his life that were holding him back:

- I learned that I do not need to always be calculated, calm, and collected. I can fail. I can make mistakes without becoming a weaker person...I faced my willingness to manipulate others so that they may see only what I want; I faced my lack of awareness to how my selfish actions affect others; I faced my arrogance and saw that it hid flaws I never wanted to accept...I learned that I have infinite flaws, infinite strengths, and infinite potential. I learned not to be scared of any of that.

\section{Clarity of Purpose and Vocation}

Many students expressed an increased sense of purpose and clarity in their vocation. During the semester, students had an opportunity to reflect on their purpose within the course and within their lives. One student, in reflecting on the assignment Who is myself and what is my purpose? discussed that this was the most important assignment for her. She wrote:

- I still find myself adding to [my understanding of myself and my purpose] and thinking about it. It is really about learning what makes you tick, and I truly believe my purpose is to help people reach their best.

In gaining a greater understanding of one's purpose, some students expressed confusion. In one student's case, this confusion was coupled with optimism and motivation to continue searching for purpose:

- This [course] has been a catapult for me to discover new things about myself, and has made me think more about my future and what I want to do after college. It may have added some confusion and complications to my life by making me re-think things, but I has opened my eyes and given me a lot to think about.

Many students discussed a transformation in how they viewed their future. One student wrote: 
- I am inspired now to make transformational change and not just little change. I now think big, something that I have not felt since a child...This experience has led me to want more in life.

Another student discussed that through this course she recognized her vocational calling and decided on making a significant change in her career path:

- In the last several months, I have taken steps towards the most drastic changes that I have ever made my life. I realized that my lifelong dream of becoming a doctor was actually my lifelong dream of becoming a nurse...I am fortunate because I found the courage to walk away from medical school and to the field where I truly belong. By this decision alone I have grown more in the last six months than in the last four years.

\section{Integration of Learning and Experiences}

The theme of self-awareness also encompasses the bridging and integration of students' learning and experiences. Students connected their learning in the classroom to their experiences and learning outside of the classroom through cocurricular experiences and in relationships with others. One student wrote about how his learning in this course helped him be more successful in his leadership role within student government:

- [The coursework] really helped my performance in my [leadership] position, [sic] I could stop and identify a certain dynamic. [The course] was like a laboratory, in the sense that we would stop and analyze what was happening in the group as it was happening. I brought this to different meetings, situations and one-on-ones with people. Taking the time to stop and look at the bigger picture or the small details helped me be more productive and effective.

Some students expressed a parallel relationship between the dynamics unfolding in the classroom and dynamics in their personal lives. One student connected communication challenges in the course to communication challenges in her relationship with her boyfriend. Through experimenting with different communication strategies in the course, she identified ways to improve her communication strategies in her relationship.

Since many students were taking the course during their senior year, they used the course as an opportunity to reflect on and make meaning of their college experience. A graduating senior discussed this in her paper:

- Each class in college allowed me to learn something independent and unique, [sic] however the sum of these classes resembles my development into an adult. I honestly believe that this class...made me aware of this 
development. [It has] allowed me to integrate my experiences from college and find growth and maturity within myself.

\section{Broader View of Leadership}

The other main theme capturing students' learning in this course is a gaining a broader view of the concept of leadership. Students had previously taken at least two and as many as six leadership courses prior to this course and had previously established understandings of leadership that tended to be fairly relational and service-oriented. Students expressed that through engaging in the group process and experiencing the concepts in action while simultaneously discussing and reflecting on the concepts, their understandings of leadership were not only solidified, but also further developed. There were three main areas in which students' views of leadership were broadened: (a) openness to diverse perspectives and roles, (b) viewing leadership as systemic and interdependent, and (c) emphasis on relationship building.

\section{Openness to Diverse Perspectives and Roles}

By engaging in the group process the students learned to have a greater appreciation for diverse perspectives and roles within a group. In learning to value this diversity, students gained an increased understanding of others and greater openness to others. One student wrote:

- We got past the surface level of knowing each other and really got to know things about each other most would not learn from a class...The stories shared by others also gave me new perspectives and ideas that I would not normally have thought of and made me a more understanding person.

Many students learned to appreciate and value diversity of perspectives and roles through experiencing conflict. Given that the course involved a great deal of group discussions and group decision-making, conflicting ideas were often present, and the students found productive ways to engage in conflict. One student discussed how examining and seeking to understand different perspectives helped him work more effectively with others:

- When I make the effort to think about situations from a different perspective, I have an open mind to everyone's ideas and thoughts. This ability also gives me more patience to work with others who have conflicting ideas.

A significant conflict that emerged in the course centered on the extent to which students verbally engaged within the group. A group dynamic related to the talkers and the non-talkers emerged. Through discussing this conflict as it was taking place the students learned to more critically examine their roles as well as 
seek to understand others. One student, who was more introverted, shared her learning from this experience:

- The people in groups I usually struggle with are the most outspoken, opinionated leaders. I have always viewed them as pushy and having the need to always get their way. Now, I realize that this type of leader is just extremely passionate about their work and has a strong desire to create change. Knowing this increased my patience for their leadership style and helps me to understand why they are so strong about their views.

\section{Leadership as Systemic and Interdependent}

Students' understandings of leadership were also broadened in recognizing the systemic and interdependent nature of leadership. Many students learned about the importance of the larger environment in which leadership takes place and how this influences the individuals and the group. One student shared her reflections on this:

- I finally understood that leadership is a mixture of personal characteristics and the environment. It is nearly impossible to define what characteristics are required of a leader, without understanding the environment of the challenge.

Students emphasized interdependence with a focus on the collective and the responsibility that individual members of the group had to each other and to the group as a whole. One student discussed this collective responsibility in terms of learning:

- We all became responsible for each other's learning, and we transformed the meaning behind the 'you' in the purpose of the class (from what I initially read to be individual) into a collective effort.

Additionally, students expressed the importance of collaboration and working together, acknowledging the power of the whole and the important piece that each person played in that whole. One student described this through the metaphor of a puzzle:

- You have to take into account everything in your environment in order to put the pieces together. In our class we had to integrate ourselves with the rest of the class. We did this balancing our backgrounds, biases, and preconceived notions, with those who are different...balancing when to assert authority, and when to let go...finding our roles in the class and how to be most effective.

Further, students felt a greater responsibility to the larger system, viewing leadership as serving one's community and making a positive difference to 
something beyond oneself. One student discussed this in his desire to affect social change:

- Being a young adult whom considers himself a leader it is my responsibility to act out against the injustices in the world today.

\section{Emphasis on Building Relationships}

The final area in which students' views on leadership were broadened through this course was an increased emphasis on building relationships within groups. The group process was a key aspect of this course, and students continuously negotiated their relationships with others, both positive and strained, within the class. Through this they learned the importance of building relationships and the impact of relationships on themselves, individually and on the group.

Building trust within the group was significant in creating meaningful and effective relationships. Many students recognized the importance of vulnerability as a basis for building this trust. Engaging the group in a check-in at the beginning of class became a common practice, which allowed the students to break down walls and become vulnerable. One student discussed the importance of this in the group's development:

- Daily opportunities to be vulnerable and allow others to start trusting each other benefited the group as a whole. The information shared may not have been life-changing...but [it] showcased the importance of building relationships with each other through trust.

Many students expressed that the openness and trust experienced in the course was very different than the relationships built in other classroom environments. One student wrote:

- I opened up more of my heart to this class than I have to some friends in my life.

Another student shared the same sentiment:

- I could only compare this to the level of trust that take [sic] years to create in close friends or a family, and I would be shocked if I ever see this in any other class throughout my academic career.

Through developing meaningful and trusting relationships with each other students learned the importance of connecting with others on deeper levels through empathy and compassion. One student, who previously held a logical approach to engaging with others in a classroom reflected on this learning: 
- I disliked the concept of empathy in the classroom. I thought it was a soft part of leadership that should be reserved only for close friends and family. Now, I feel that empathy is one of the cornerstones of leadership.

Students recognized that while building relationships was pivotal to a successful group, there are other key aspects of a group that should not be neglected. A student wrote:

- Knowing your team or group on a personal level is absolutely crucial, but I have learned that I need to ensure that such a belief does not translate into placing more emphasis on relationships than effective group work and healthy conflicts.

\section{Summary of Results}

Findings from this study demonstrate students' learning from the capstone leadership course in two major themes as (a) increased self-awareness and (b) broader view of leadership. Through engaging in the learning experiences of reflection, the group process, and feedback, students' increased understanding of self consisted of three prominent subthemes: (a) challenge and affirmation of leadership styles and roles, (b) clarity of purpose and vocation, and (c) integration of learning and experiences. Further, students' views of leadership were broadened in the three subthemes of (a) openness to diverse perspectives and roles, (b) leadership as systemic and interdependent, and (c) emphasis on relationship building.

\section{Discussion}

The learning from this leadership course reflects many outcomes desired in leadership education and higher education today (Astin \& Astin, 2000; Council for the Advancement of Standards in Higher Education, 2009; Huber, 2002; Keeling, 2004). Outcomes of critical thinking, interpersonal competence, intrapersonal competence, effective collaboration and teamwork, and citizenship are identified as pivotal in students' success in college and after college (Association of American Colleges and Universities, 2011; Keeling, 2004). Similar values and competencies are goals of leadership education initiatives (Huber, 2002; Komives, Dugan, Owen, Slack, \& Wagner, 2011).

In this capstone course students came to view themselves and leadership more complexly. Their recognition of the importance of the intrapersonal, interpersonal, and systemic levels of leadership reflects leadership scholars' contemporary perspectives on leadership. Heifetz and Linsky (2002) and Wheatley (2006) emphasize the interdependent levels of leadership environments and systems rather than isolated pieces or parts of a system. The Social Change Model of Leadership (Komives \& Wagner, 2009) and Emotionally Intelligent Leadership Model (Shankman \& Allen, 2008), two leadership frameworks developed with a 
college student population in mind, similarly recognize the individual, group, and organizational levels of the leadership process. While the students' had previously been exposed to leadership frameworks such as these that emphasize relational, process-oriented, and systemic aspects of leadership, the experiential, studentcentered, and inquiry-focused nature of the capstone course helped solidify students' learning.

The learning expressed by the students related to their self-understanding and ability to build relationships and work with others in a group environment suggests growth in their psychosocial development and cognitive development. Psychosocial development, which focuses on the formation of identity, encompasses students' interpersonal and intrapersonal development. Chickering and Reisser's (1993) seven vectors encompass the developmental tasks students face while in college. Many of the vectors were evident in the findings from this study including (a) developing mature interpersonal relationships, (b) interpersonal competence, (c) effectively managing and expressing emotions, (d) moving from autonomy toward interdependence, and (e) establishing identity. Further, the findings from this study suggest growth in students' cognitive development, or students' patterns of thought and how they make meaning (Perry, 1981). Perry's schema of cognitive and ethical development captures the process by which students' cognitive processes become more complex and move from dualistic thinking toward more multiplistic and relativistic thinking. The movement toward recognizing and valuing diverse perspectives within the group identified in this study along with the reframing that some students made about themselves, others', working in groups, and leadership demonstrates a shift in cognitive capacity.

Students' learning in the course also suggests growth in their leadership identity development (LID) - the developmental process through which college students develop a leadership identity (Komives, Owen, Longerbeam, Mainella, \& Osteen, 2005). The LID model describes a six-stage process in which students' leadership identity moves from positional and dependent toward more relational and interdependent. Encompassed in this process of moving toward a more complex leadership identity is a broadening view of leadership, more interdependent relationships with others, the ability to work effectively with others and in groups which are themes evident within the findings from this current study. The authority roles and dynamics within the classroom were identified as environmental factors instrumental in this learning, helping move students toward a more complex, relational, and interdependent leadership identity.

\section{Implications for Practice}

Findings from this study suggest the value that student-centered and inquiryfocused pedagogies have in leadership education. Particularly when seeking to help students apply their learning to practice, constructing a classroom environment that alters traditional classroom authority dynamics and decision- 
making process to reflect more closely dynamics that may be more reflective of out-of-classroom leadership settings and groups can provide many opportunities for learning and development. Including students in the learning process and tasking students with guiding this process requires instructors to release authority and control, opening up many opportunities for students to learn, experiment, and challenge themselves and the group.

While such pedagogical strategies and classroom environments may not conducive for all courses, aspects of these strategies may allow for student investment, ownership, and learning from the process. For example, students could be tasked with identifying the standards by which they should be graded on an assignment or the class could be tasked with making a decision about how to spend class time while at the same time providing opportunities for them to observe their process of making a decision as a group, applying leadership concepts to the observation. Many students described classroom discourse, group process, and even conflict as critical aspects of the course contributing to their learning. Incorporating opportunities that allow for this can help students in their self-awareness and their understanding of leadership. Finally, many students identified trust as pivotal in the group process. Opening up and exhibiting vulnerability were key in building trust. Identifying ways in which the students and instructor can be open and vulnerable can assist with the group process and thus student learning.

\section{Areas for Future Research}

As suggested by Dugan, Bohle, Gebhardt, Hofert, Wilk, and Cooney (2011), this study examined one specific leadership program in terms of student learning. Continued qualitative study of individual leadership programs will help with program quality and student learning. This study identifies teaching strategies and aspects of a classroom environment and the student learning that accompanied these strategies. While the findings span three sections, the study only focuses on one specific course at a single institution. Additional research into pedagogical approaches such as these in other leadership programs and with other student populations can contribute to a better understanding of effecting leadership education practices. Research on this topic can also be enhanced through examining students longitudinally throughout the course of a leadership minor or long-term program and post-college. Studying students' learning about themselves and leadership as well as their psychosocial development, cognitive development, and leadership identity development can provide additional insight into leadership education and student learning and development.

\section{Conclusion}

Ernest Boyer (1997), a key influence on higher education in the United States and a former U.S. Commissioner of Education, and President of the Carnegie Foundation for the Advancement of Teaching, wrote, "[G]reat teachers create a 
common ground of intellectual commitment. They stimulate active, not passive, learning and encourage students to be critical, creative thinkers, with the capacity to go on learning after their college days are over" (p. 24). As leadership educators we are committed to creating this common ground of intellectual commitment about which Boyer wrote. This study focused on such an effort by examining student learning in a capstone course in which we incorporated action inquiry, case-in-point, and problem-based learning into a student-centered and inquiry-focused pedagogy. The findings suggest a great deal of student learning that reflects the learning goals and outcomes of leadership education and higher education today. 


\section{References}

Association of American Colleges and Universities. (2011). Association of American Colleges and Universities. Retrieved from http://www.aacu.org.

Astin, A. W., \& Astin, H. S. (2000). Leadership reconsidered: Engaging higher education in social change. Battle Creek, MI: W. K. Kellogg Foundation.

Barbour, J. (2006). Team building and problem-based learning in the leadership classroom: Findings from a two-year study. Journal of Leadership Education, 5(2), 28-40.

Baxter Magolda, M. B., \& King, P. M. (Eds.) (2004). Learning partnerships: Theory and models of practice to educate for self-authorship. Sterling, VA: Stylus Publishing, LLC.

Binard, K., \& Brungardt, C. (1997). Learning leadership: Assessing students at the community college of Denver. The Journal of Leadership Studies, $4(4), 128-140$.

Boyatzis, R. (1998). Transforming qualitative information. Thousand Oaks, CA: SAGE.

Boyer, E. L. (1997). Scholarship reconsidered: Priorities of the professoriate. Stanford: The Carnegie Foundation For the Advancement of Teaching.

Brungardt, C., Greenleaf, J., Brungardt, C., \& Arensdorf, J. (2006). Majoring in leadership: A review of undergraduate leadership degree programs. Journal of Leadership Education, 5(1), 4-24.

Chickering, A. W., \& Reisser, L. (1993). Education and identity (2 ed.). San Francisco: Jossey-Bass.

Council for the Advancement of Standards in Higher Education (2009). CAS professional standards for higher education $\left(7^{\text {th }}\right.$ ed.). Washington, DC: Author.

Cress, C. M., Astin, H. S., Zimmerman-Oster, K., \& Burkhardt, J. C. (2001). Developmental outcomes of college students' involvement in leadership activities. Journal of College Student Development, 42(1), 15-27.

Creswell, J. W. (2007). Qualitative inquiry and research design: Choosing among five approaches $\left(2^{\text {nd }}\right.$ ed.). Thousand Oaks, CA: SAGE.

Cunningham, W. G., \& Cordeiro, P. A. (2006). Educational leadership: A problem-based approach ( $3^{\text {rd }}$ ed.). Boston, MA: Allyn \& Bacon. 
Daloz Parks, S. (2005). Leadership can be taught. Boston: Harvard Business School Press.

DiPaolo, D. G. (2002). Voices of leadership (pp. 1-41). Ann Arbor: University of Michigan.

Duch, B. J., Groh, S. E., \& Allen, D. E. (2001a). Why problem-based learning?: A case study of institutional change in undergraduate education. In B. J. Duch, S. E. Groh \& D. E. Allen (Eds.), The power of problem-based learning (pp. 3-11). Sterling, VA: Stylus Publishing, LLC.

Duch, B. J., Groh, S. E., \& Allen, D. E. (Eds.) (2001b). The power of problembased learning. Sterling, VA: Stylus Publishing, LLC.

Dugan, J. P. (2011). Research on college student leadership development. In S. R. Komives, J. P. Dugan, J. E. Owen, C. Slack \& W. Wagner (Eds.), The handbook for student leadership development (pp. 59-84). San Francisco: Jossey-Bass.

Dugan, J. P., Bohle, C. W., Gebhardt, M., Hofert, M., Wilk, E., \& Cooney, M. A. (2011). Influences of leadership program participation on students' capacities for socially responsible leadership. Journal of Student Affairs Research and Practice, 48(1), 65-84.

Dugan, J. P., \& Komives, S. R. (2007). Developing leadership capacity in college students: Findings from a national study. College Park, MD: National Clearinghouse for Leadership Programs.

Eich, D. (2008). A grounded theory of high-quality leadership programs: Perspectives from student leadership development programs in higher education. Journal of Leadership \& Organizational Studies, 15(2), 176187.

Haber, P. (2011). Formal leadership program models. In S. R. Komives, J. P. Dugan, J. E. Owen, C. Slack \& W. Wagner (Eds.), The handbook for student leadership development ( $2^{\text {nd }}$ ed., pp. 231-258). San Francisco: Jossey-Bass.

Heifetz, R. A., \& Linsky, M. (2002). Leadership without easy answers. Cambridge: Harvard University Press.

Huber, N. S. (2002). Approaching leadership education in the new millennium. Journal of Leadership Education, 1(1), 1-11. 
Keeling, R. P. (2004). Learning reconsidered: A campus-wide focus on the student experience. Washington, DC: NASPA and ACPA.

Klenke, K. (2008). Qualitative research in the study of leadership. Bingley, UK: Emerald Group.

Komives, S. R. (2011). Advancing leadership education. In S. R. Komives, J. P. Dugan, J. E. Owen, C. Slack \& W. Wagner (Eds.), The handbook for student leadership development (pp. 1-34). San Francisco: Jossey-Bass.

Komives, S. R., Dugan, J. P., Owen, J. E., Slack, C., \& Wagner, W. (Eds.) (2011). The handbook for student leadership development $\left(2^{\text {nd }}\right.$ ed.). San Franciscso: Jossey-Bass.

Komives, S. R., Owen, J. E., Longerbeam, S. D., Mainella, F. C., \& Osteen, L. (2005). Developing a leadership identity: A grounded theory. Journal of College Student Development, 46(6), 593-611.

Komives, S. R., \& Wagner, W. (2009). Leadership for a better world: Understanding the social change model of leadership development. San Francisco: Jossey-Bass.

Lincoln, Y. S., \& Guba, E. G. (1985). Naturalistic inquiry. Newbury Park, CA: Sage Publications.

Merriam, S. B. (2009). Qualitative research: A guide to design and implementation. San Francisco: Jossey-Bass.

Millis, B. J. (2010). Why faculty should adopt cooperative learning approaches. In B. J. Millis \& J. Rhem (Eds.), Cooperative learning in higher education: Across the disciplines, across the academy (pp. 1-10). Sterling, VA: Stylus Publishing, LLC.

Northouse, P. G. (2007). Leadership: Theory and practice $\left(4^{\text {th }}\right.$ ed.). Thousand Oaks, CA: Sage Publications.

Perry, W. G. (1981). Cognitive and ethical growth: The making of meaning. In A. W. Chickering (Ed.), The modern American college (pp. 76-116). San Francisco: Jossey-Bass.

Posner, B. Z. (2009). A longitudinal study examining changes in students' leadership behavior. Journal of College Student Development, 50(5), 551563.

Roberts, D. C., \& Ullom, C. (1989). Student leadership program model. NASPA Journal, 25(1), 67-74. 
Scroggs, L. E., Sattler, J. L., \& McMillan, B. (2009). The undergraduate leadership mosiac: A challenge of shared purpose. Journal of Leadership Education, 8(1), 48-58.

Seemiller, C. (2006). Impacting social change through service learning in an introductory leadership course. Journal of Leadership Education, 5(2), 4149.

Shankman, M. L., \& Allen, S. J. (2008). Emotionally intelligent leadership: A guide for college students. San Francisco: Jossey-Bass.

Smist, J. (2011). Cocurricular programs. In S. R. Komives, J. P. Dugan, J. E. Owen, C. Slack \& W. Wagner (Eds.), The handbook for student leadership development ( $2^{\text {nd }}$ ed., pp. 287-304). San Francisco: JosseyBass.

Torbert, B. (2004). Action inqiury: The secret of timely and transforming leadership. San Francisco: Berrett-Koehler Publishers.

Wheatley, M. J. (2006). Leadership and the new science: Discovering order in a chaotic world ( $3^{\text {rd }}$ ed.). San Francisco: Berrett-Koehler Publishers.

Williams, J. R., \& Townsend, C. D. (2003). The intellectual capacity of leadership competencies as perceived by past members of a collegiate sophomore leadership course. (No. ED482472): Education Resources Information Center (ERIC).

Zimmerman-Oster, K., \& Burkhardt, J. C. (1999). Leadership in the making: Impact and insights from leadership development programs in U.S. colleges and universities. Battle Creek, MI: W. K. Kellogg Foundation. 


\section{Author Biographies}

Paige Haber-Curran, Ph.D., is assistant professor and program coordinator for the Student Affairs in Higher Education master's program in the Department of Counseling, Leadership, Adult Education, and School Psychology at Texas State University-San Marcos. Paige earned her doctorate. in Leadership Studies from the University of San Diego and her M.A. in College Student Personnel from the University of Maryland. Her research focuses on college student leadership development, women and leadership, student leadership programs, college student learning, and emotional intelligence. Paige is actively involved with the International Leadership Association, ACPA-College Student Educators International, and the LeaderShape Institute.

Daniel Tillapaugh, Ph.D., is the postdoctoral fellow in higher education at the University of Maine. Dan is a graduate of the doctoral program in Leadership Studies at University of San Diego and has a M.Ed. from the University of Maryland's College Student Personnel program. He has over 10 years of experience as a student affairs administration prior to becoming a faculty member. His research focuses on college student leadership development and gender and sexual orientation issues in higher education. Active in ACPA-College Student Educators International, he is currently chair of the Standing Committee on Men and Masculinities. 